\title{
Otantik Liderliğin Belediye Çalışanlarının Performansına Etkisinde Pozitif Psikolojik Sermayenin Rolü
}

\author{
DOI: 10.26466/opus.643236 \\ * \\ Rifat İraz - Namik Ata ** \\ * Prof.Dr., Selçuk Üniversitesi, İktisadi ve İdari Bilimler Fakültesi, Konya/Türkiye \\ E-Posta: rifat@selcuk.edu.tr \\ ORCID: 0000-0002-2774-8428 \\ ** Doktora Öğrencsi., Selçuk Üniversitesi, Sosyal Bilimler Enstitüsü, Konya/Türkiye \\ E-Posta: ata.namik@gmail.com \\ ORCID: 0000-0001-8033-7954
}

\begin{abstract}
Öz
Örgütlerde çalşan performansının artırlması verimlilik ve etkinlik açısından önem arzetmektedir. Örgütsel davranış ve liderlik tarzları çalı̧an performansını artırılması hususunda etkili olabilirler. Bu çalışma, kurumlarda otantik liderliğin çalışan performansı üzerindeki etkisinde psikolojik sermayenin rolünü tespit etmek amacıyla yapılmıştır. Araştırma Konya'da bir merkez ilçe belediye başkanlı̆̆ında icra edilmiştir. Literatürde belediye kurumlarında yapılan çalışmalardaki eksikliği doldurması ümit edilmektedir. Araştırmanın evrenini ilçe belediyesinde görevli 170 memur personel oluşturmaktadır. Personelin hepsine anket gönderilmiş, 125 adedinden dönüş alınmış, 121 anket geçerli sayılmıştır. Ankette otantik liderlik ölçeğine ait 16 soru, çalışan performansı ölçeğine ait 6 soru, pozitif psikolojik sermaye ölçeğine ait 24 soru yer almıştır. Nümerik parametrelerin istatistik analizleri Bağımsız T-Test ve Tek Yön Anova ile araştırılmıştır. Varyans homojenliği sağlanamadığ için çoklu karşılaştırmalar Tamhane's T2 testi ile incelenmiştir. Çalışmanın korelasyon analizleri ise Pearson ve Spearman'ın Korelasyon test teknikleri ile incelenmiştir. Analizleri yaparken SPSS 24 programından yararlanılmıştır. Analiz sonucunda pozitif psikolojik sermayenin, otantik liderlik tarzı ile çalışanların performansı arasındaki ilişkide kısmi aracılık etkisine sahip olduğu tespit edilmiştir.
\end{abstract}

Anahtar Kelimeler: Otantik Liderlik, Çalışan Performansı, Pozitif Psikolojik Sermaye, Belediye Çalışanlarn 


\title{
The Role of Positive Psychological Capital in The Effect of Authentic Leadership on The Performance of Municipal Employees
}

\begin{abstract}
Increasing employee performance in organizations is important in terms of efficiency and effectiveness. Organizational behavior and leadership styles can be effective in improving employee performance. This study has been conducted to determine the role of psychological capital in the effect of authentic leadership on employee performance in institutions. The study has been applied in the the mayor of a central district in Konya. It is hoped that it will fill the lack of the studies applied in the municipal institutions in the literature. The universe of the study consists of 170 civil servants in the district municipality. Questionnaires have been sent to all of the staff, 125 of them have been returned and 121 questionnaires have been considered valid. The questionnaire has been consisted of 16 questions related to authentic leadership scale, 6 questions related to employee performance scale and 24 questions for positive psychological capital. Statistical analysis of numerical parameters has been examined with Independent T-Test and One Way Anova. As homogeneity of variance could not be obtained, multiple comparisons have been examined by Tamhane T2 test. Correlation analyzes of the study have been examined with Correlation test techniques of Pearson and Spearman. SPSS 24 program has been used for analysis. As a result of the analysis, it has been determined that positive psychological capital had a partial mediation effect on the relationship between authentic leadership style and employee performance.
\end{abstract}

Keywords: Authentic Leadership, Employee Performance, Positive Psychological Capital, Municipal Employees 


\section{Giriş}

Psikoloji biliminin amaçları zararları onarmak, kişileri güçlendirmek ve sorunlara engel olmaktır. Ama yıllar boyunca bu bilim, insanların yanlışlarının neler olduğuna odaklanmış, yanlışları üzerinde çalışmalar yapmıştır. Pozitif psikoloji tüm bu olumsuz tavırlara tepki olarak ortaya çımıştır. İnsanın doğrularına odaklanan ve bunları iş hayatında kullanan pozitif psikolojik sermaye bugünlerde gündemde olan bir kavramdır. Sermayesi insan olan pozitif psikolojik sermaye öz yeterlilik, umut, iyimserlik ve psikolojik dayanıklılık gibi soyut alt kavramları kapsamaktadır. Örgütlerin değişime ayak uydurabilmesi, sürdürülebilir rekabet avantajı elde edebilmesi, hayatta kalabilmesi ve yaratıcı olabilmesi için finansal sermayeler ve diğer kaynaklar yetersiz kalabilmektedir. Bu açıdan bakıldığında ben kimim sorusuna verilen olumlu sorular ile başlayan ve bu yönünü iş hayatına yansıtan kişiler en büyük sermayenin farkına varmışlardır.

İlk kez Martin Seligman tarafindan ortaya atılan psikoloji biliminin insanın olumlu yönlerini anlayıp geliştirmeye yönlenmesi (E. P. Seligman ve Csikszentmihalyi, 2000) gerektiğine dair pozitif örgütsel davranış alanındaki değişimler, klasik lider tiplerini ikinci plana atmıştır. Çalışanların pozitif taraflarını orta çıkarabilecek onları güdüleyecek liderlere ihtiyaç doğmuştur. Çevresine güven verebilecek, samimi, şeffaf, olumlu, kendini bilen bu lider tarzına otantik lider denmektedir. Otantik liderler dürüstlük gibi içten gelen bu özelliklerinin yanında takipçilerini geliştirmek için yeterli yeteneklere ve güdüye de sahip liderler olarak bilinmektedir. Takipçileri sayesinde otantik liderler gerekli olumlu örgüt kültürünü oluşturup, kurumlarını başarıya götürebilirler.

Bu kavramlar günümüzde örgütlerde giderek daha fazla yer bulmakta ve çalışan performansı üzerinde yaptıkları olumlu katkılardan dolayı işverenler otantik liderleri tercih etmektedirler. Pozitif psikolojik sermaye ve otantik liderlik birbirini tamamlayan ve çalışan performansına etki eden iki unsur olabilir. Bu çalışmada otantik liderlik, pozitif psikolojik sermaye ve çalışan performansı konuları incelenmektedir. 


\section{Kavramsal Çerçeve}

\section{Otantik Liderlik}

Liderlik insanları ortak bir amaca yöneltme sanatı ve kapasitesi olup, bir şeyi başkalarına benimsetmek ve bunu yaptırabilmek gücü olarak tarif edilebilir. Bu güce sahip olan kişiye de lider denilmektedir. Liderliği bir fonksiyon olarak düşünürsek; liderin kendisi, izleyicileri, amaçlar, ortam ve koşullar bu fonksiyonun alt parçalarıdır (Şimşek ve Çelik, 2017, s.69). Yönetici ve lider; aralarında benzerlikler bulunsa da farklı kavramlardır. Lider; insanı motive edip belirli amaçlar doğrultusunda belirli yönlere sevk ederken, yönetici; mevcut işleri yürütüp idare eden, verilen yetkiler ile yapılması gereken işleri takip eden, planlama yapan sonunda da elde edilen sonuçları değerlendiren birisidir. Lider ise yetkilerinden ziyade kendi kabiliyetlerini kullanmaktadır (Taşan, 2015, s.11,12).

Liderlik konusunu açıklayan dört temel yaklaşım olduğunu söylemek mümkündür. Bunlar; özellikler, davranışsal, durumsal ve çağdaş (güncel) yaklaşımlar olup, birbirlerini tamamlayan yaklaşımlardır. Hiçbirisi tek başına liderlik konusunu açıklamaya yeterli değildir. Herbiri birbirini tamamlayan hususları içerisinde barındırmaktadır (Şimşek ve Çelik, 2017, s.72). En eski liderlik teorisi özellikler teorisidir. İlk çağlardan itibaren araştırmacılar hangi özelliklerin lideri, grubun diğerlerinden ayırdığı konusunu araştırmışlardır. Özellikler yaklaşımına göre liderin göze batan ve üstün özelliklerinin, takipçilerinin üzerinde etkisi olduğu ve bu özelliklerin takipçilerini yönlendirebilmesinde anahtar rolünü üstlendiği fikri kabul edilmiştir (Tercan, 2017, s.2).

Özellikler teorisinde liderlerin sahip olduğu özellikler tespit edilmeye, liderlerin fiziksel ve kişisel olmak üzere farklı özellikleri olduğu açıklanmaya çalışılmıştır. Bu konuda birçok araştırma yapılmıştır. Fiziksel özellikler olarak; boy, kilo, cinsiyet, yaş, sağlık durumu, kişilik özellikleri olarak ise; güven veren, duygusal açıdan dengeli, kendine güvenen, açık sözlü, samimi, güzel konuşma yeteneği olmak gibi hususlar örnek gösterilmiştir. Fakat, yapılan araştırmalarda etkili ve başarılı liderlerin aynı özellikleri taşımadıklarının belirlenmesi, grup içinde liderden daha fazla özelliklere sahip olanların bulu- 
nabilmesi bu teorinin zayıf halkası olmuştur. Aynı zamanda teori, lider özelliklerinin ölçülmesinin güçlüğü ve bir özelliğin değişik biçimlerde anlaşılması açısından eksik bulunmaktadır (Koçel, 2018, s.594,595).

Liderlik konusu ile ilgili yapılan araştırmalar sonucunda sadece özellikler kuramının liderlik kavramını açıklamada yeterli olmadığı ortaya konulmuştur. Bundan dolayı araştırmacılar liderin fiili davranışlarını incelemeye başlamışlar ve davranışsal yaklaşımlar ortaya çıkmıştır. Bu araştırmalara "Ohio Eyalet Üniversitesi Modeli, Michigan Üniversitesi Araştırmaları, Blake ve Mouton'un Yönetsel Diyagramı, Mc Gregor' un X ve Y Kuramları ile Likert' in Dörtlü Yaklaşım Modeli” örnek verilebilir (Şimşek ve Çelik, 2017, s.73). Davranışsal yaklaşımda liderlerin çevresine olan davranışları ve yaptıkları hareketler mühimdir. Bu yaklaşımda özellikler yaklaşımında olduğu gibi kişilerin lider olarak doğdukları fikri değil, lider olmak için kişilerin eğitilebilecekleri fikri kabul görür (Hirlak, 2015, s.17).

Liderlik yaklaşımlarından bir diğeri de durumsal liderlik yaklaşımıdır. Durumsal yaklaşım, liderlik kavramına içinde bulunulan durum ve şartlarla ilişkisi açısından bakmaktadır (Teke, 2017, s.11). Bu yaklaşımda başarılı liderlik denince, liderin ortaya çıkan her durumla başa çıkması beklenmektedir. Uygun bir liderin seçilebilmesi ise liderin yargısı ve durumsal faktörlerin dikkate alınması ile ilgilidir. Bu sebepten dolayı, liderlik rolünü üstlenmek için ortaya çıkacak kişilerin seçilmesinde durumsal faktörler rol oynamaktadır (Jogulu ve Wood, 2006, s.239). Başlıca durumsal kuramlar şunlardır; Fred Fiedler'in Liderlik Teorisi, Amaç-Yol Teorisi, Paul Hersey ve Ken H. Blanchard'ın Durumsal Liderlik Yaklaşımı, Vroom-Yetton'un Normatif Liderlik Yaklaşımı ve Reddin'in Üç Boyutlu Lider Etkinliği kuramları (Teke, 2017, s.11).

Klasik veya geleneksel liderlik yaklaşımlarının değişen çevre koşullarından dolayı yeterli olmaması, akademik ve uygulama açıdan "çağdaş liderlik yaklaşımları "olarak adlandıracağımız yeni kuramların doğmasına yol açmıştır (Çiftçi, 2018, s.42). Çağdaş liderlik değerleri ve uygulamaları, bireyin temel değerlerine ve amaçna ait öz farkındalığının otantikliğini açıklamakta, liderliğin motivasyonel etkilerini, liderlerin değer ve davranışlarının tutarlılığını ve değerlerinin kendisini takip edenlerin değerleri ile olan uyumunu incelemektedir (Sparrowe, 2005, s.149). Yani çağdaş liderlik kuramları sadece lider tutum ve davranışlarına değil, bu tutum ve davranışların takipçileri ile 
ilişkilerini de araştırır. Çağdaş liderlik yaklaşımları olarak "Etkileşimci ve Dönüşümcü Liderlik”, “Karizmatik Liderlik”, “Otantik Liderlik”, ve "Stratejik Liderlik" gibi teoriler sayılabilir (Çiftçi, 2018, s.43).

Otantik liderlik çağdaş liderlik yaklaşımları içinde pozitif unsurları barındıran (Avolio vd., 2004, s.801), oluşturduğu iyi çalışma ortamı, ılımlı örgüt iklimi sayesinde örgütsel çıtılara olumlu katkı sağlayan (Gardner vd., 2005:343) ve son yıllarda en çok araştırılan liderlik tarzlarından birisidir. Çalışanların pozitif duygularına yönelik olan otantik liderlik tarzı, otantiklik kavramına dayanır. Literatürde 1990'lı yıllardan beri tartışılmaya başlanan bir kavram olsa da tarihsel geçmişi oldukça eskidir (Karatürk, 2015, s.11). Fransızca "authentique" sözcüğünden dilimize giren otantik kelimesi TDK'ya göre "eskiden beri mevcut olan özelliklerini taşıyan" anlamındadır (TDK.com, 2019). Yani gerçeğe, aslına uygun, doğru, düzgün ve orijinal anlamina gelmektedir.

Otantiklik, bir kişinin günlük faaliyetlerinde kendi iç duyguları, güdüleri, eğilimleri ve doğrularına göre davranmasıdır (Kernis, 2003, s.13,14). Yani otantik olarak davranmak demek bireyin kendi değerleri, tercihleri ve ihtiyaçlarına göre hareket etmesidir. Diğer bir ifade ile cezadan kaçmak, ödül kazanmak veya diğerlerini memnun etmek için gösterilen sahte davranışın tam tersidir (Akgündüz, 2012, s.19). Ayrıca otantiklik tarih içinde yaşanmış dile getirilmiş bir kavramdır. Tıpkı Yunus gibi Mevlâna gibi otantiklik de "kendini bilme" yi merkeze alır ve bunu kendisine temel dayanak yapar (Karatürk, 2015, s.13).

Otantik liderlik takipçileri ile birlikte gelişir, onlarla bir değer sahibi olabilir. Takipçiler, liderin davranışını şekillendirebilir (Eagly, 2005, s.459). Liderin otantikliğine takipçileri karar verebilir, otantiklik kontrolü liderde olan davranışların, diğer insanlar tarafından nasıl göründüğüdür (Goffee ve Jones, 2005, s.1). Otantik lider yapısını dört şekilde açıklayabiliriz. Birincisi otantik liderlerin liderlikleri taklit değildir. Onlar olduğu gibi davranırlar, özgündürler. İkincisi terfi veya onur için değil, inançları ve gerçek benliklerinin gereği öncülük ederler. Üçüncüsü, değerleri ve inançları doğrultusunda davranırlar, söyledikleri ve yaptıkları arasında bir tutarlılık vardır. Sonuncu özellik ise, otantik liderler değer temelli bir misyonun sürdürülmesinde kendi inançlarından yola çıkarak öncülük ederler (Shamir ve Eilam, 2005, s.396,397). 
Alanyazında yapılan çalışmalara göre otantik liderliğin dört boyutu özfarkındalık, ilişkilerdeki şeffaflık, dengeli ve tarafsız değerlendirme ile içselleştirilmiş ahlaki bir bakış açısıdır. Öz-farkındalık; otantik liderin dünyaya nasıl anlam verdiği ve bu anlamın kendini algılama biçimini nasıl etkilediğinin farkındalığıdır. Bu özellik kişinin kendini bilmesine, güçlü ve zayıf olduğu yönlerini keşfetmesine yardım etmektedir. Otantik lider, takipçilerini nasıl etkilediğinin farkında olmakla beraber kendi değer yargılarına, düşünce sistemine göre hareket etmektedir. Bunun yanında güvenilir ve ahlaki yönü yüksek olan bir kişiliğe sahip olmak, otantik liderlerin en karakteristik özelliklerindendir (Avolio vd., 2004, s.806-807).

Şeffaflık; liderlerin ilişkilerinde net ve doğrudan olması demektir. Otantik liderin kendi düşüncelerini ve doğrularını dolaylı olarak değil direkt takipçilerine aktarabilmesi ve böylece otantik bilincin sergilenmesi yoluyla oluşan (Gardner vd., 2005, s.358) ilişkilerdeki şeffaflık, takipçilerin liderin gerçek bilincini görmelerine vesile olmaktadır.

Dengeli ve tarafsız değerlendirme; liderin bir karar vermeden önce durumu bütün boyutları ile değerlendirmesi ve yansız bir şekilde karar vermesi demektir. Ayrıca, liderlerin güçlü ve zayıf yönlerini bilerek kabullenmesi ve bu konuda tarafsız olması da bu unsur içinde yer almaktadır (Kernis ve Goldman, 2006, s.298).

İçselleştirilmiş ahlaki bir bakış açısı; yapılan çalışmalarda otantik liderlerin doğasında ahlaki/etik yönü yüksek yapıya sahip oldukları ifade edilmiştir. Bu boyut otantik liderlikle ilgili yapılan çalışmalarda içsel kural ve pozitif ahlaki bakış açısı olarak ortaya konulan boyutların, benzer yönlerinin olduğunun anlaşılmasının ardından bir araya toplanmasıyla ortaya çıkmıştır. İçselleştirilmiş ahlak anlayışı bireyin değer kalıpları, seçimleri ve gereksinimleri ile uyum içinde davranışlar sergilemesi demektir (Tabak vd., 2012, s.96).

\section{Çalışan Performansı}

Performans kavramı; örgüt içerisinde görev yapan grupların ya da çalışanların önceden belirlenmiş amaçlara ulaşmak için neler yaptıklarını, çabalarını ve sonunda neye ulaştıklarını belirtmek üzere kullanılan bir kavramdır (Buldu, 2016, s.59). Kelime anlamına göre; bir işin üstesinden gelmek, bir kimsenin üzerine düsen görevi etkin bir biçimde tamamlaması demektir (Akyol, 2015, s.59). 
Performans alanyazında bağlamsal ve görev performansı olarak iki alt başlıkta incelenmektedir. Bağlamsal Performans; doğrudan göreve yönelik çıktılara etki etmemekle birlikte, görevin başarılması için ihtiyaç duyulacak örgütsel, sosyal ve psikolojik çevredeki bireysel çıtıları ifade eder. Görev Performansı ise; bireyin işindeki yetkinliğini ifade eder. Bireyin görev ve sorumluluklarındaki doğrudan çıktılar, görev performansına örnek teşkil etmektedir (Kılınç ve Yener, 2019, s.690-691).

Örgütlerin istenilen hedefe ulaşması çalışan personelin performansına bağlıdır. Hizmet içi eğitim, terfi, ücret artışı, prim, ikramiye, tatil gibi unsurlar personelin performansını artırmak yönünde etkili birer stratejidir. Çalışan performansının yüksek olması örgütler, yöneticiler ve çalışanlar için de önemli bir konudur. İşlerinde başarı sağlamaları personele gurur ve doyum kaynağı olmakla birlikte; yüksek bir maaş, iyi bir kariyer ve çevresinde iyi bir itibar kazandıran önemli bir faktördür (Tayfun ve Çatır, 2013, s.120). Performansın unsurları; verimlilik, etkinlik ve kalitedir. Ayrıca bireysel, takım ve örgütsel olmak üzere üç ayrı boyutu vardır.

Verimlilik; örgütlerin ve çalışanların performansında önemli bir unsurdur. Genel bir tanımlama ile verimlilik; bir üretim ya da hizmet sisteminin ürettiği çıktı ile, bu çıktıyı yaratmak için kullanılan girdi arasındaki ilişkidir. Çalışan performansında etkinlik; bireysel açısından da takım açısından da önemlidir. Takımların ve bireylerin etkinlik seviyelerini artırmak için amaçların iyi bir şekilde belirlenmesi ve de bunların iyi bir şekilde anlatılması gereklidir. Bu amaçlara ulaşmayı örgütün ve çalışanın istemesi de diğer bir husustur. Bunu başarmak ise liderin tavır ve davranışları ile ilgilidir. Son unsur olan kalite; müşteri memnuniyetini yükselten en önemli husustur. Müşteriler ürün ve hizmetlerden kaliteli olması şartı ile en yüksek verimi almaya çalışan kişilerdir. Arz ve talebi ortaya çkaran müşterilerin ihtiyaç ve talebidir (Buldu, 2016, s.59-61).

\section{Pozitif Psikolojik Sermaye}

Bu kavramdan ilk bahseden Seligman (2002, s.4)'a göre psikoloji biliminin üç temel misyonu vardır; zihinsel hastalıkları iyileştirmek, bireylerin hayatını daha anlamlı ve verimli kılmak, son olarak ise bireylerin yeteneklerinin, güçlü yönlerinin ve potansiyellerinin farkına varmalarını sağlamaktır. Fakat 
Seligman'a göre psikoloji bilimi bu son iki misyonunu yerine getirmemektedir (Akçay, 2011, s.77). Seligman bu tespiti yaptıktan sonra psikoloji bulgularının insanları nasıl daha normal, daha mutlu, daha başarılı ve daha iyi olabileceklerini öğretmek için kullanılması gerektiğini vurgulayarak "pozitif psikoloji" kavramını ileri sürmüştür (Keleş, 2011, s.346).

Yapılan araştırmalar pozitif psikolojik sermayenin, pozitif psikoloji ve örgütsel davranışın pozitif etkileri ile gelişmeye başladığını göstermektedir (Avey vd., 2009, s.689). Pozitif psikoloji birey ya da grupların işleyiş ve gelişimine katkıda bulunan süreçlerin incelenmesidir. İnsanlardaki yanlışlarla değil, doğrular ile ilgilenen bunların nasıl geliştirilebileceğine odaklanan bir kavramdır. Pozitif duygular, pozitif kişilik özellikleri ve pozitif örgüt bilimi olarak da açıklanabilir. Pozitif örgütsel davranış ise; gruplarda performansı artırmak için pozitif eğilimli insan kaynaklarının, güçlü yanlarını ve psikolojik kapasitelerini artırmaya çalışan bilimsel çalışmalardır (Yılmaz ve Yılmaz, 2016, s.130).

Bir işletmeyi sadece yazılı bilançosuna, maddi sermaye ve karlılık durumuna bakarak değerlendirmemiz bizi yanıltabilir. Çalışanların iyimserlik, öz yeterlilik, umut ve dayanıklılık özelliklerini kapsayan psikolojik sermayesi; yetenekleri, sabrı, yaratıcılığı, ileri görüşlülüŭü, bilgisi ve eğitim düzeyinin oluşturduğu beşerî sermayesi; ile ilişkilerini, ağların, normlarını ve değerlerini tanımlayan sosyal sermayesi ise organizasyonun bilançosunda görünmeyen, onu başarıya götüren ve maddi olmayan sermayeleridir (Özkan, 2018, s.16).

Günümüzün rekabet koşullarında, diğer örgütlerle rekabet edebilmek ve üstünlük sağlayabilmek maddi sermayenin yanında, artık maddi olmayan beşerî ve sosyal sermayelere de; yani eğitimli, deneyimli ve bilgili çalışanlara da sahip olmaktan geçmektedir. Örgütlerde insan öğesinin giderek önem kazanması ile sermaye anlamı daha da genişlemiş olup, "psikolojik sermaye" bu kavrama ilave olmuştur. Psikolojik sermaye hem piyasanın zorlu rekabet koşullarında hem de piyasada yaşanan krizlerde kurumların ayakta kalmasını ve dayanıklılı̆̆ını sağlayan en önemli unsurlardan biridir (Özkan, 2018, s.16).

Psikolojik Sermaye, kişinin verimliliğini, üretkenliğini olumlu yönde etkileyen psikolojik durumlardır. Psikolojik sermayenin en önemli bileşeninin in- 
san sermayesi olduğu, bu da kişinin kendisini nasıl algıladığına bağlıdır (Özkan, 2018, s.16). Pozitif psikolojik sermaye ve diğer sermaye türleri arasındaki farklar aşağıda yer alan Tablo 1'de izah edilmiştir.

Tablo 1. Rekabet avantajı için sermayenin çeșitlenmesi (Luthans vd., 2004, s.46)

\begin{tabular}{|c|c|c|c|}
\hline $\begin{array}{l}\text { Geleneksel } \\
\text { Finansal Sermaye }\end{array}$ & $\begin{array}{l}\text { Beşerî } \\
\text { Sermaye }\end{array}$ & $\begin{array}{l}\text { Sosyal } \\
\text { Sermaye }\end{array}$ & $\begin{array}{l}\text { Pozitif } \\
\text { Psikolojik Sermaye }\end{array}$ \\
\hline $\begin{array}{l}\text { Neye } \\
\text { Sahipsiniz }\end{array}$ & $\begin{array}{l}\mathrm{Ne} \\
\text { Biliyorsunuz }\end{array}$ & $\begin{array}{c}\text { Kimi } \\
\text { Tanyorsunuz }\end{array}$ & $\longrightarrow$ Kimsiniz \\
\hline $\begin{array}{l}\text {-Finansal Varlıklar } \\
\text {-Somut Varlıklar } \\
\text { (fabrika, teçhizat, } \\
\text { patentler, veriler) }\end{array}$ & $\begin{array}{l}\text {-Tecrübe } \\
\text {-Eğitim } \\
\text {-Yetenekler } \\
\text {-Bilgi } \\
\text {-Fikir }\end{array}$ & $\begin{array}{l}\text {-illişkiler } \\
\text {-İletişim Ağları } \\
\text {-Arkadaşlar }\end{array}$ & $\begin{array}{l}\text { - Öz Yeterlilik } \\
\text { - Umut } \\
\text { - İyimserlik } \\
\text { - Psikolojik } \\
\text { Dayanıklılık }\end{array}$ \\
\hline
\end{tabular}

\section{Teorik Model ve Hipotezler}

Kuram; bilimsel araştırmalarda değişkenler arasında olabileceği varsayılan ilişkilerin dayandırıldığı ve literatürde bilimsel araştırma süreciyle yapılan çalışmalarla desteklenen bilimsel açıklamalar olarak tanımlanmaktadır (Yener, 2018b). Bu çalışmada otantik liderlik ve psikoljik sermaye arasındaki ilişki LÜE (Lider-Üye-Etkileşim) ve Sosyal Mübadele kuramları ile açıklanabilir. Otantik liderler içinde bulundukları çevreye psikolojik, etik ve ahlaki farkındalığı getirmekte ve örgütlerinde bireylerarası saygıyı yerleştirmektedirler. Bireylere içinde bulunduğu etik ve ahlaki çevrenin normları içinde ve en doğal halleriyle davranmaktadırlar (Avolio vd., 2004, s.811). Otantik liderlerin bireyler ile güçlü ve özel bir iletişim bağı bulunmaktadır. Bu şekilde de LÜE kuramına göre (Leader-Member-Exchange Theory, Lider-Üye-Etkileşim Kuramı) karşılıklı farkındalığı örgütlerine yerleştirmektedirler (Yener, 2018a, s.5).

LÜE kuramına göre liderlerin izleyicileriyle kurmuş oldukları güvenilir, karşılıklı ve birey odaklı iletişimin çıtılar üzerinde etkili olabileceği değerlendirilmektedir (Burns ve Otte, 1999, s.226; Graen ve Uhl-Bien, 1995, s.224). LÜE kuramına göre otantik liderler, izleyicilerinin üzerinde farkındalığa dayalı davranışlarda istenen değişiklikleri gerçekleştirebilir (Heather M, 2012). İzleyicilerin de kendileriyle özel iletişim şekli kuran liderlere karşı tutumları- 
nın olumlu olacağı değerlendirilebilir. Bu açıdan otantik liderlerin hem pozitif psikolojik sermayeye hem de çalışan performansına olumlu etkileri olabilir.

Ayrıca otantik liderler karşılıklı saygı çerçevesini oluş̧urduğunda diğer bir kuram olan Sosyal Değişim Kuramına (Social Exchange Theory) göre üyeler de aynı şekilde olumlu bir karşılık vereceklerdir. Çünkü Sosyal Değişim Kuramı (Social Exchange Theory, Blau (1964)); çalışana verilen destek, ilgi, saygı ve güven karşılığında çalışanların bunların karşılığını vermek için bütün kaynaklarını örgütsel amaçların doğrultusunda kullanacaklarını önermektedir.

\section{Otantik Liderlik ve Çalışan Performansı}

Organizasyonlarda işgörenlerin performansını etkileyen en önemli değişkenin liderlik olduğu ileri sürülebilir (Hırlak, 2015, s.159). Otantik lider çalışanları etkileyerek onların performansının yükselmesini sağlar, sonuç olarak bu da örgütün performansının yükselmesine neden olabilir (Buldu, 2016, s.70). Otantik liderler öz farkındalıkları, öz düzenlemeleri ve pozitif modellemeleri yoluyla çalışanların da otantikliğinin gelişimini teşvik edebilirler. Bu da onların refahlarına, iyi oluşlarına ve sürdürülebilir gerçek performanslarına ulaşmalarında katkı sağlayacağı söylenebilir (Avolio ve Gardner, 2005, s.317).

İstanbul'da yer alan sağlık, otomotiv ve eğitim alanında çalışan kişiler arasında yapulan çalışmada; otantik liderliğin çalışan motivasyonunu ve iş performansını etkilediği bulunmuştur (Tercan, 2017, s.67). İstanbul'da cam sektöründe öncü bir kurumsal firmada modern liderlik tarzlarından karizmatik liderlik ve çalışan performansı arasındaki ilişkiyi tespit etmek için yapılan bir diğer çalışmada karizmatik liderlik algıları ile performans algıları arasında pozitif yönde bir ilişki tespit edilmiştir. Çalışanların karizmatik liderlik alg1ları arttığında performansları da artmaktadır (Buldu, 2016, s.87).

LÜE (Lider-Üye-Etkileşim) ve Sosyal Mübadele kuramının yanında Hirschman (1970) 'in kaçma-konuşma kuramına göre de otantik liderlik ve çalışan performansı ilşkisi açıklanabilir. Bu kurama göre çalışanların düşüncelerine ve katkılarına değer verdiğinde çalışanlar konuşmayı yani örgüt için fedakarlık yapma yolunu seçeceği düşünülmekte, aksi durumda ise kaçma yolunu seçeceği düşünülmektedir. Otantik liderler çalışanlara değer verirler, onların öz farkındalıklarını artırırlar; bu da performanslarını olumlu yönde 
etkileyebilir. Otantik liderler bir örgütte performansı ve rekabet avantajını artırırlar. Bu kişiler, aynı zamanda bu özelliklerini ortaklarında ve takipçilerinde de geliştirmeye yatkındırlar (Luthans vd., 2005, s.265). Bu fikirlerden, kuramlardan ve daha önce yapılan araştırmalardan hareketle aşağdaki hipotez oluşturulmuştur:

- H1: Yöneticilerin otantik liderlik özellikleri çalışanların performansını anlamlı ve olumlu yönde etkilemektedir.

\section{Otantik Liderlik ve Pozitif Psikolojik Sermaye}

Otantik liderler, izleyicilerinde psikolojik sermaye özelliklerinin gelişmesinde önemli bir rol oynarlar. Psikolojik sermayelerini geliştirebilir ve onlara örnek olabilirler (Topaloğlu ve Özer, 2014, s.161). Otantiklik doğallık, içtenlik ve samimiyet gibi olumlu davranışları vurguladığı için pozitif psikolojinin ilgi alanına girmektedir. Pozitif psikolojinin bireylerin düşünce ve yaşayışlarında ortaya çıkan mutsuzluğa olumlu yaklaşımlar üretmesi gibi, otantik liderliğin de bu mutsuzluğu önleyici etkisinin olabileceği düşünülmektedir. Çünkü otantik yaklaşım ve liderlik; bireyin yaşayacağı iç çatışma ve organizasyonda oluşacak kişilerarası çatışmayı engelleyebilir (Yener, 2018a, s.6).

Çiftçi'nin 2018 yılında Orta ve Doğu Karadeniz Bölgesi sinırları içinde yer alan, 11 ilde faaliyet göstermekte olan, 4 ve 5 yıldızlı otel işletmelerinde yaptığı çalışmada pozitif psikolojik sermayenin, otantik liderlerin çalışanların işe adanmışlıkları üzerindeki etkisinde kısmi aracılık yaptığı tespit edilmiştir (Çiftçi, 2018, s.162). Batman ilindeki resmi ilkokullarda ve resmi ortaokullarda görev yapan yöneticiler arasında otantik liderlik ve psikolojik sermaye düzeylerinin karşılaştırılması konulu çalışmada otantik liderliğin psikolojik sermaye ile ilişkisinin pozitif yönde olduğu kanaatine ulaşılmıştır (Taşan, 2015, s.98). Gaziantep, Adıyaman ve Kilis illerinin yer aldığı TRC1(kalkınma planı ile ilgili) bölgesinde görev yapan hastane çalışanları arasında yapılan araştırmada, otantik liderlik boyutlarının tamamı ile çalışanların psikolojik sermaye boyutlarını tamamı arasında pozitif yönde ve zayıf düzeyde anlamlı ilişkilerin olduğu bulunmuştur (Hırlak, 2015). Türk Standartları Enstitüsü (TSE) beyaz yakalı çalışanları arasında yapılan araştırmada, dönüşümcü liderliğin pozitif psikolojik sermayeyi pozitif yönde anlamlı olarak etkilemekte olduğu sonucuna ulaşılmıştır (Şengüllendi ve Şehitoğlu, 2017, s.123). 
İncelenen bu çalışmalara göre yöneticilerin sahip olduğu otantik liderlik özelliğinin, çalışanların sahip olduğu psikolojik sermaye düzeylerini pozitif bir şekilde etkilediği değerlendirilebilir. Bu değerlendirmelerin ve kuramların ışığında aşağıdaki ikinci hipotez oluşturulmuştur:

- H2: Yöneticilerin otantik liderlik özellikleri çalışanların pozitif psikolojik sermaye düzeylerini anlamlı ve olumlu yönde etkilemektedir.

\section{Pozitif Psikolojik Sermaye ve Çalışan Performansı}

Türk lojistik sektöründe faaliyet gösteren bir işletmenin çalışanları arasında yapılan araştırma sonuçlarına göre psikolojik sermayenin işgören performansını etkilediği görülmüştür. Psikolojik sermayenin yükselmesiyle birlikte işgören performansının da yükseldiği ve işgörenlerin örgütsel özdeşleşme seviyelerinde anlamlı ve olumlu etkilerin oluştuğu tespit edilmiştir (Ateş ve Turgut, 2018, s.792). Türkiye'deki 68 vakıf üniversitesinde, 2016-2017 eğitimöğretim yılı bahar döneminde görev yapan akademik personel arasında yapılan araştırmada psikolojik sermaye ile bireysel performans arasında yüksek düzeyde pozitif yönlü bir ilişki tespit edilmiştir (Özkan, 2018, s.254).

Bireyler karşılaştıkları otantik lider davranışlarıyla kişilerarası saygıyı, güveni ve hoşgörüyü yaşayarak liderden gelen olumlu davranışların karşılığında örgütlerin lehine fedakarlık yapabilir (Yener, 2018a, s.6) ve performansların artırabilirler. Otantik tarzda davranan bir liderin görmek istediği, aynı kendisi gibi doğal davranan bireylerdir. Otantik liderin davranışlarının istikrarlı olması kendisini rol model yapacak bu da çalışanlarını etkileyecektir. Bu fikirlere, önceki çalışma sonuçlarına, LÜE ve Sosyal Değişim kuramlarına dayanarak aşağıdaki hipotez oluşturulmuştur.

- H3: Çalışanların pozitif psikolojik sermaye düzeyleri, performanslarını anlamlı ve olumlu yönde etkilemektedir.

\section{Otantik Liderlik, Çalışan Performansı ve Pozitif Psikolojik Sermaye}

Otantik liderler, örgütte çalışanın yanlışlarından çok onların doğruları ile uğraşırlar. Bu şekilde bireyin güçlü olmasına katkıda bulunurlar. Otantik liderlik bunu yaparken, pozitif psikolojik olgudan da faydalanırlar (Taşan, 2015, s.58). Otantik liderlik performansı artırırken psikolojik sermayenin iyimser 
ortamından yararlanabilirler. İşletmelerin örgütsel olarak hedeflerine ulaşmaları için liderlik ve pozitif psikolojik sermaye kavramları artık önemli konulardır (Şengüllendi ve Şehitoğlu, 2017, s.116). Psikolojik sermaye, otantik liderliğin önemli bir parçasıdır. Otantik liderler bir organizasyonda psikolojik sermayeyi ortaya çıkarmaya vasıta olabilmektedirler ve bunu yaparak performansı geliştirmeye öncülük ederler (Topaloğlu ve Özer, 2014, s.161). Otantik liderlerin göstereceği doğal, samimi, içten davranışlarıyla oluşacak etkileşim ve çalışma ortamında çalışanlar liderin davranışlarını tecrübe edecekler (Yener, 2018a, s.8), liderin davranışlarının istikrar göstermesi durumunda sosyal mübadele kuramina (social exchange theory) göre pozitif psikolojik sermayeleri olumlu etkilenecek ve geliştireceklerdir. Yine LÜE (Lider-ÜyeEtkileşim) kuramına göre otantik liderlerin izleyicilerinde değişiklikleri gerçekleştirebileceği düşünülebilir.

Topaloğlu ve Özer'in 2014 yılında Denizli'de faaliyet gösteren bir holdingin tüm çalışanları arasında yaptığı çalışmada, psikolojik sermaye ile iş performansı arasındaki ilişki ve otantik liderliğin düzenleyici etkisi incelenmiştir. Buna göre, otantik liderlik algısının psikolojik sermaye ile iş performansı ilişkisini kısmi biçimde düzenlediği bulunmuştur. Çalışanların psikolojik sermayelerinin iş performansını geliştirici etkisi, otantik liderliğin daha pozitif algilandığı koşullarda daha yüksek olacağı sonucuna varılmıştır (Topaloğlu ve Özer, 2014, s.168).

Bu bağlamda otantik liderliğin çalışanların performansını olumlu ve anlamlı bir şekilde etkilediği bir ilişkide pozitif psikolojik sermayeninin bu etkinin bir kısmını üzerine alabileceği önerilmektedir. Bu fikirler ışığında aşağıdaki hipotez oluşturulmuştur.

- H4: Pozitif psikolojik sermaye, otantik liderlik tarzı ile çalışanların performansı arasındaki ilişkide aracılık rolüne sahiptir.

\section{Araştırma Modeli}

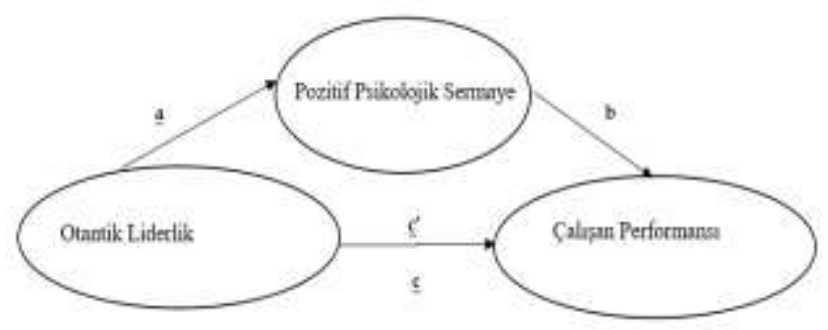




\section{Yöntem}

\section{Araştırmanın Konusu, Amacı ve Önemi}

Çevre hızla değişmektedir, daha önceden belirlenmemiş görevler daha sık ortaya çıabilmektedir. Bunları yönetebilecek örgütü başarıya götürebilecek bir liderliğe ihtiyaç vardır (Şengüllendi ve Şehitoğlu, 2017:116). Devamlı gelişen teknoloji, sürekli artan rekabet, örgütleri değişime zorlamaktadır. Yapısal/fiziksel, finansal veya teknolojik gibi geleneksel sermaye türleri günümüzdeki rekabet ve değişim ortamının ihtiyaçlarını karşılayamamaktadır Artık işletmeler için insan faktörünün merkezde olduğu beşerî sermaye, sosyal sermaye ve en önemlisi psikolojik sermaye oldukça önemli bir etken olmuştur (Luthans ve Youssef, 2004, s.4-5). Kurumların hedeflerine ulaşması, rekabet güçlerini artırabilmeleri için çalışan performansını en üst seviyeye getirmeleri, bunun sonucunda etkin ve verimli ve kaliteli bir çıktı alabilmeleri gereklidir. Buna ulaşabilmek için otantik liderlik ve pozitif psikolojik sermaye kavramları günümüzün en gözde ve önemli kavramlarından olmuştur. Bunlardan dolayı, iki kavramın çalışan performansına etkileri, üçünün birbirleri arasında ilişki olup olmadığı araştırmanın konusu olarak seçilmiş ve bu üç kavramın incelenmesi hedeflenmiştir. Sonuç olarak araştırmada modern liderlik tarzlarından olan ve her geçen gün daha çok gündeme gelen otantik liderliğin çalışan personele olan etkisi, bu etkileşimde son günlerde değerli bir hal alan çalışanların pozitif psikolojik sermaye düzeylerinin rolünün tespit edilmesi amaçlanmıştır.

Yönetim ve örgütsel psikoloji literatüründe otantik liderlik ile ilgili birçok araştırma yapılmış olmasına rağmen, söz konusu kavramın çalışan performansı üzerinde etkisini tespit ederken, bu etkide pozitif psikolojik sermayenin aracılık etkisini ölçen araştırma eksikliği de bu araştırmanın yapılmasını önemli kılmaktadır.

\section{Araştırmanın Evreni-Örneklem-Sınırlılkklar}

Belediyeler günümüzde hizmet yoğun bir şekilde çalışan kamu kurumlar1dır. Dolayısı ile bu kurumlar için insan kaynakları ve niteliği ile insan ile insan kaynağının performansı ve otantik liderliğin buna etkisini önemli kılmaktadır. Bundan dolayı araştırmanın evrenini, Konya ilimizin merkez ilçelerinden 
olan bir belediye teşkilatında görevli 170 memur personel oluşturmaktadır. Görevli personelin tamamına ulaşılmaya çalışılmış, fakat 125 personelden geri dönüş alınmıştır. Ancak yanlış ve eksik doldurulan 4 adet anket değerlendirmeye alınmamış ve 121 anket değerlendirmeye alınmıştır. Araştırmanın toplam evreni 170 kişi olup, örneklem miktarı ise \%95 güvenirliğe göre 118 kişidir (Survey.com, 2019). Evrene (170) ve ulaşılan anket miktarına (121) göre örneklem yeterlidir (Gürbüz ve Şahin, 2018:72). Araştırma Konya ili ve belediye çalışanları ile sınırlıdır.

\section{Veri Toplama Aracı ve Ölçekler}

Araştırmanın amacı doğrultusunda belirlenen hipotezleri test edebilmek için nicel bir araştırma yapılmıştır. Araştırmada nicel veri toplama tekniklerinden birisi olan anket formundan faydalanılmıştır. Anket formu dört bölüm ve toplam 46 sorudan oluşmaktadır. İlk bölümde yaş, cinsiyet, eğitim durumu, toplam çalışma yılı, kurundaki çalışma yılı ve pozisyon bilgilerinin yer aldığı 6 soru bulunmaktadır.

İkinci bölümde, çalışmanın bağımsız değişkeni olan otantik liderlik alg1sını ölçmek için Walumbwa vd. (2008) tarafından geliştirilen ve Tabak vd. (2012) tarafından Türkçe uyarlaması ile geçerlilik ve güvenirlik çalışması yapılan "Otantik Liderlik Ölçeği" (Authentic Leadership Questionnaire ALQ) kullanılmıştır. Otantik liderlik ölçeği 4 boyuttan (Bireysel farkındalık, dengeli davranış, ahlaki davranış, şeffaflık) ve 16 ifadeden oluşmaktadır.

Üçüncü bölümde, pozitif psikolojik sermaye düzeyini ölçmek için Luthans vd. (2007) tarafından geliştirilen 24 sorudan oluşan pozitif psikolojik sermaye ölçeği kullanılmıştır. Ölçek pozitif psikolojik sermayeye ilişkin; umut, psikolojik dayanıklılık, iyimserlik ve öz-yeterlilik olmak üzere toplam dört boyuttan oluşmaktadır. Ölçeğin Türkçe uyarlaması ile geçerlilik ve güvenirlik çalışması Çetin ve Basım (2012) tarafından yapılmıştır. Son bölümde ise, çalışan performansını ölçmek için (Buldu, 2016, s.75) ile (Tayfun ve Çatır, 2013, s.121) tarafından kullanılan ve 6 maddeden oluşan bireysel performans ölçeğinden faydalanılmıştır. 


\section{Bulgular}

İstatistiksel analizler için SPSS Windows version 24.0 paket programı kullanılmış ve $\mathrm{P}<0.05$ istatistiksel olarak anlamlı kabul edilmiştir. Ölçeklere ait faktör analizlerini değerlendirilmesinde ilk aşama olan “KMO (Kaiser Meyer Olkin) Örneklem Uygunluğu" değerleri ile verilerin homojen bir dağılım gösterip göstermediği; Barletts Testi (Barlett's Test Of Sphericity) ile de faktör analizinin dayandığı korelasyonların istatistiksel olarak anlamlı olup olmadığı değerlendirilmiştir. Otantik liderlik ölçeğine yönelik yapılan KMO analizi soncuna $(0,889)$ göre verilerin homojenliği faktör analizine uygun düzeyde olduğu yine benzer şekilde Bartlett testine göre faktörler arası korelasyon düzeyinin analiz yapılmasına uygun düzeyde olduğu $(p<0,05)$ gözlenmiştir. Çalışan Performansı ölçeğinde toplamda $\mathrm{K}=6$ tane madde gözlenmiştir ve yapılan faktör analizinde yeterli düzeyde bir faktör ayrılması gözlenmediğinden bu ölçeğin faktör analizi yapılamamıştır. PPS ölçeğine yönelik yapılan KMO analizi soncuna $(0,897)$ göre verilerin homojenliği faktör analizine uygun düzeyde olduğu yine benzer şekilde Bartlett testine göre faktörler arası korelasyon düzeyinin analiz yapılmasına uygun düzeyde olduğu $(p<0,05)$ gözlenmiştir.

Tablo 2. Güvenirlilik Analizi Sonuçlan

\begin{tabular}{lllllll} 
& $\mathbf{N}$ & Min. & Max & Ortalama & Std. Sapma & $\begin{array}{l}\text { Cronbach's } \\
\text { Alfa }\end{array}$ \\
\hline Ölçek OTL & 121 & 56,97 & 13,40 & 22,00 & 98,00 & 0,880 \\
\hline Ölçek PER & 121 & 24,89 & 3,49 & 16,00 & 30,00 & 0,801 \\
\hline Ölçek PPS & 121 & 93,26 & 11,92 & 62,00 & 116,00 & 0,895 \\
\hline
\end{tabular}

Otantik liderlik ölçeğinin Cronbach's Alfa değeri 0,880 olarak ölçülmüştür. Çalışan performansı ölçeğinin 0,801 ve pozitif psikolojik sermaye ölçeğinin değeri ise 0,895 olarak ölçülmüştür. Ölçeklerin Cronbach's Alfa değerlerinin yüksek düzeyde olduğu, bu da anketin güvenilir olduğunu göstermektedir.

Tablo 3'te görüldüğü üzere çalışma yapılan kişilerin, \%10,7'si ilköğretim mezunu iken, \%18,2 lise mezunu, \%20,7 ön lisans ve \%50,4'ünün ise lisans üzeri eğitim programından mezun olduğu saptanmıştır. Kişilerin \%79'u evli iken, \%21'i bekardır. Katılanların \%24,8'i kadın, \%75,2'si erkektir. Araştır- 
maya katılanların \%94,2'sinin pozisyonu çalışan \%5,8'i ise yöneticidir. Araştırmadaki kişilerin \%14,9' unun çalışma süresi 1-3 yıl arasında iken, \%13,2'i 36 yıl arasında, \%26,4'ünün 6-10 yıl ve \%10,7'sinin ise 10-15 yıl arasında olduğu tespit edilmiştir. Ayrıca kişilerin \%2,0'sinin çalışma süresi 15-20 yıl ve $\% 2,2$ 'sinin ise çalışma süresinin 20 yıldan fazla olduğu belirlenmiştir.

Demografik bilgilere göre ölçek analizleri de yapılmıştır. Demografik özellikler ile otantik liderlik, çalışan performansı ve pozitif psikolojik sermaye arasında anlamlı bir ilişki bulunamamıştır. Demografik özelliklerin ölçeklere herhangi etkisi görülmemiştir.

Tablo 3. Araştırmaya Katılanlara ait Demografik Özellikler (N=121)

\begin{tabular}{|c|c|c|c|}
\hline Değişken & & Frekans (n) & Yüzde (\%) \\
\hline \multirow[t]{2}{*}{ Cinsiyet } & Erkek & 379 & 24,8 \\
\hline & Kadın & 66 & 75,2 \\
\hline \multirow[t]{5}{*}{ Yaş } & 20 Yaş ve Altı & 1 & 0,8 \\
\hline & 20-29 Yaş & 29 & 24,0 \\
\hline & 30-39 Yaş & 58 & 47,9 \\
\hline & 40-49 Yaş & 23 & 19,0 \\
\hline & 50-59 Yaş & 10 & 8,3 \\
\hline \multirow[t]{4}{*}{ Eğitim Durumu } & İlkokul & 13 & 10,7 \\
\hline & Ortaöğretim & 22 & 18,7 \\
\hline & Ön Lisans & 22 & 20,7 \\
\hline & Lisans ve Üstü & 61 & 50,4 \\
\hline \multirow[t]{2}{*}{ Medeni Durum } & Evli & 94 & 79,0 \\
\hline & Bekar & 25 & 21,0 \\
\hline \multirow[t]{2}{*}{ Unvan } & Çalışan & 114 & 94,2 \\
\hline & Yönetici & 7 & 5,8 \\
\hline \multirow[t]{6}{*}{ Çalışma Süresi } & $1-3 Y_{1}$ & 18 & 14,9 \\
\hline & 3-6 Yil & 16 & 13,2 \\
\hline & 6-10 Yil & 32 & 26,4 \\
\hline & 10-15 Y1l & 26 & 21,5 \\
\hline & $15-20 Y_{11}$ & 13 & 10,7 \\
\hline & 20 yıl ve Üzeri & 16 & 13,2 \\
\hline
\end{tabular}


Tablo 4. Otantik Liderlik Ölçeğinde Yer Alan Sorulara ait Tanımlayıcı Özellikler

\begin{tabular}{lcc}
\hline & Ort. & Ss. \\
\hline İlişkilerde Şeffaflık & & \\
\hline 1. Ne demek istiyorsa onu açıkça söyler. & 4,0 & 1,0 \\
\hline 2. Hata yaptığında kabul eder. & 3,1 & 1,2 \\
\hline 3. Herkesin düşündüklerini söylemesini teşvik eder. & 3,5 & 1,3 \\
\hline 4. İnsanlara acı gerçekleri söyler. & 3,7 & 1,1 \\
\hline 5. Açığa vurduğu duyguları hissettikleriyle tam olarak aynıdır. & 3,5 & 1,2 \\
\hline İçselleştirilmiş̧ Ahlak Anlayışı & 3,7 & 1,2 \\
\hline 6. İnandıklarıla yaptıkları tutarlıdır. & 3,8 & 1,2 \\
\hline 7. Kararlarını değer yargılarına göre verir. & 3,7 & 1,3 \\
\hline 8. İnsanların da kendi değer yargılarının arkasında durmasını ister. & 3,5 & 1,2 \\
\hline 9. Ahlaki boyutu yüksek standartlara dayalı zor kararlar verir. & & \\
\hline Bilgiyi Dengeli Değerlendirmek & 3,0 & 1,2 \\
\hline 10. Derinden inandıklarıyla ters olan görüşlerin belirtilmesini ısrarla ister. & 3,8 & 1,2 \\
\hline 11. Karar vermeden önce ilgili bilgiyi enine boyuna inceler. & 3,6 & 1,2 \\
\hline 12. Sonuca varmadan önce değişik görüşleri dikkatle dinler. & 3,4 & 1,1 \\
\hline Öz Farkındalık & 3,6 & 1,1 \\
\hline 13. Başkalarılyla etkileşimi/iletişimi geliştirmek için geri besleme arayışı içinde olur. & 3,6 & 1,2 \\
\hline 14. Yeteneklerinin başkaları tarafından nasıl değerlendirildiğini bilir. & 3,5 & 1,2 \\
\hline 15. Önemli konulardaki tavrının ne zaman yeniden değerlendirilmesi gerektiğini bilir. & & \\
\hline 16. Özel/şahsi durumlarının insanları nasıl etkilediğini anlar ve bunu onlara belli eder. & & \\
\hline
\end{tabular}

Otantik liderlik ölçeğindeki (Tablo 4) alt boyutlara ait aritmetik ortalamalar şu şekildedir: İlişkilerde şeffaflık aritmetik ortalaması 3,56; içselleştirilmiş ahlak anlayışı 3,675; bilgiyi dengeli değerlendirmek 3,46; öz farkındalık 3,525. Otantik liderlik ölçeğinin aritmetik ortalaması ise 3,56'dır. En yüksek ortalama içselleştirilmiş ahlak anlayışında görülmektedir. Verilen cevaplara bakıldığında en çok katılımın birinci anket sorusu olan "ne demek istiyorsa onu açıç̧a söyler" ifadesidir. En düşük olan ise "derinden inandıklarıyla ters olan görüşlerin belirtilmesini ssrarla ister" ifadesidir.

Tablo 5. Çalışan Performansı Ölçeğinde Yer Alan Sorulara ait Tanımlayıcı Özellikler

\begin{tabular}{lll}
\hline & Ort. & Ss. \\
\hline 1. İş hedeflerime fazlasıyla ulaşırım. & 4,0 &, 9 \\
\hline 2.Sunduğum hizmet kalitesinde standartlara fazlasıyla ulaştı̆̆ımdan eminim. & 4,1 &, 8 \\
\hline 3. Görevlerimi tam zamanında tamamlarım. & 4,4 &, 7 \\
\hline 4. Bir sorun gündeme geldiğinde en hizlı şekilde çözüm üretirim. & 4,1 &, 8 \\
\hline 5. Moralim yüksektir. & 3,9 &, 9 \\
\hline 6. Devamsızlık oranlarım düşüktür. & 4,4 &, 8 \\
\hline
\end{tabular}


Çalışan personel performansı aritmetik ortalaması 4,148 olarak bulunmuştur. Personelin kendi performansını dördün üzerinde, yani iyi bir seviyede gördüğü söylenebilir.

Tablo 6. Pozitif Psikolojik Sermaye Ölçeğinde Yer Alan Sorulara ait Tanımlayıcı Özellikler

\begin{tabular}{|c|c|c|}
\hline & Ort. & Ss. \\
\hline 1. Bu iş yerinde işler asla benim istediğim şekilde yürümez. & 2,7 & 1,1 \\
\hline 2. Bu aralar kendim için belirlediğim iş amaçlarımı yerine getiriyorum. & 3,6 & 1,2 \\
\hline 3. Bir grup iş arkadaşıma bir bilgi sunarken kendime güvenirim. & 4,3 & 8 \\
\hline 4. Çalışma alanımda, hedef / amaç belirleme konusunda kendime güvenirim. & 4,3 & 8 \\
\hline $\begin{array}{l}\text { 5. Daha önceleri zorluklar yaşadığım için, işimdeki zor zamanların üstesinden ge- } \\
\text { lebilirim. }\end{array}$ & 4,2 & 8 \\
\hline 6. Herhangi bir problemin çözümü için birçok yol vardır. & 4,1 & 1,0 \\
\hline 7. Genellikle, işimdeki stresli durumları sakin bir şekilde hallederim. & 3,7 & 9 \\
\hline 8. İşimde bir terslikle karşılaştığımda, onu atlatma konusunda sıkıntı yaşıyorum. & 2,6 & 1,0 \\
\hline 9. İsimde benim için belirsizlikler olduğunda, her zaman en iyisini isterim. & 4,1 & 9 \\
\hline 10. Eğer zorunda kalırsam, işimde kendime yeterim. & 4,3 & 8 \\
\hline 11. Eğer işimde bir şeyler benim için yanlış gidecekse, o şekilde gider. & 2,5 & 1,2 \\
\hline $\begin{array}{l}\text { 12. Eğer çalışırken kendimi bir tıkanıklık içinde bulursam, bundan kurtulmak için } \\
\text { birçok yol bulabilirim. }\end{array}$ & 4,0 & 1,0 \\
\hline 13. İşimde birçok şeyi halledebileceğimi hissediyorum. & 4,2 & 8 \\
\hline 14. İşimle ilgili şeylerin daima iyi tarafını görürüm. & 3,9 & 9 \\
\hline $\begin{array}{l}\text { 15. Yönetimin katıldığı toplantılarda kendi çalışma alanımı açıklarken kendime } \\
\text { güvenirim. }\end{array}$ & 4,0 & ,9 \\
\hline 16. Uzun dönemli bir probleme çözüm bulmaya çalışırken kendime güvenirim. & 4,1 & 8 \\
\hline 17. Şu anda, işimde kendimi çok başarılı görüyorum. & 4,0 & 8 \\
\hline 18. İşimle ilgili gelecekte başıma ne geleceği konusunda iyimserim. & 3,7 & 1,1 \\
\hline 19. İşime "Her şeyde bir hayır vardır" şeklinde yaklaşıyorum. & 4,1 & 1,0 \\
\hline 20. Şu anda iş amaçlarımı sıkı bir şekilde takip ediyorum. & 4,2 & 8 \\
\hline $\begin{array}{l}\text { 21. Organizasyonun stratejisi konusundaki tartşmalara katkıda bulunmada ken- } \\
\text { dime güvenirim. }\end{array}$ & 4,0 & ,9 \\
\hline 22. İşimdeki zorlukları genellikle bir şekilde hallederim. & 4,2 & 8 \\
\hline $\begin{array}{l}\text { 23. Organizasyon dışındaki kişilerle (ziyaretçiler, tedarikçiler, müşteriler...vs.) } \\
\text { problemleri konuşmak için temas kurarken kendime güvenirim. }\end{array}$ & 4,3 & 8 \\
\hline 24. Mevcut iş amaçlarıma ulaşmak için birçok yol düşünebilirim. & 4,2 & 8 \\
\hline
\end{tabular}

Psikolojik sermaye ölçeği, toplam 24 ifadeden oluşmakta olup; "İyimserlik" boyutu 1, 9, 11, 14, 18, 19; "Psikolojik dayanıklılık" boyutu 5, 7, 8, 10, 13, 22; "Umut" boyutu 2, 6, 12, 17, 20, 24; "Öz yeterlik" boyutu ise 3, 4, 15, 16, 21, 23 numaralı ifadelerle ölçülmektedir. 1, 8 ve 11. ifadeler ters puanlanmıştır (Karatürk, 2015:86). 
İyimserlik alt boyutu 3,5; Psikolojik Dayanıklılık alt boyutu 3,86; Umut alt boyutu 4,016; Öz yeterlilik alt boyutu 4,16; Pozitif Psikolojik Sermaye ölçeği aritmetik ortalaması 3,886 olarak bulunmuştur. Otantik liderlik ölçeğinde olduğu gibi pozitif psikolojik sermaye ölçeğinin ortalaması da iyi çıkmıştır.

Tablo 7. Otantik Liderlik, Çalışan Performansı ve Psikolojik Pozitif Sermaye Arasındaki Korelasyon Analizi Sonuçlarn

\begin{tabular}{|c|c|c|c|c|c|}
\hline & Ort. & S.S. & 1 & 2 & 3 \\
\hline $\begin{array}{l}\text { 1.Otantik Liderlik } \\
\text { r Korelasyon Katsayısı } \\
\text { p Annlam Değgri (2-kuyruk) } \\
\text { n Örnek Büyüklüğü }\end{array}$ & 3,56 & 0,837 & $\begin{array}{c}1 \\
119\end{array}$ & & \\
\hline $\begin{array}{l}\text { 2.Çalışan Performansı } \\
\text { r Korelasyon Katsayısı } \\
\text { p Annlam Değeri (2-kuyruk) } \\
\text { n Örnek Büyüklüğgu }\end{array}$ & 4,148 & 0,582 & $\begin{array}{c}0,304^{* *} \\
0,001 \\
118\end{array}$ & 1 & \\
\hline $\begin{array}{l}\text { 3.Pozitif Psikolojik Ser. } \\
\text { r Korelasyon Katsayısı } \\
\text { p Anlam Değgri (2-kuyruk) } \\
\text { n Örnek Büyüklüğü }\end{array}$ & 3,886 & 0,497 & $\begin{array}{c}0,232^{*} \\
0,012 \\
117\end{array}$ & $\begin{array}{c}0,704^{* *} \\
0,000 \\
119\end{array}$ & 1 \\
\hline
\end{tabular}

Bağımsız değişkenlerin bağımlı değişken ile olan korelasyonları (r) değerleri yukarıdaki gibidir. Buna göre her iki bağımsız değişken ile bağımlı değişken arasındaki ilişkiler anlamlıdır. Tabloda, araştırmaya katılan kişilerin otantik liderlik, çalışan performansı ve pozitif psikolojik sermaye'ye ait korelasyon ilişkilerine ait bilgiler "korelasyon katsayısı ve örneklem büyüklüğ̈̈" şeklinde raporlanmıştır. Araştııılan korelasyon ilişkisi otantik liderlik, çalışan performansı puanları ve pozitif psikolojik psikoloji puanları, üzerinden yürütülmüş olup; söz konusu puanlar, uygulanan anketlerden elde edilen veriler esas alınarak oluşturulmuştur.

Otantik liderlik ile çalışan performansı arasında pozitif yönlü 0,304 katsayılık bir ilişki söz konusudur. Otantik liderlik puanındaki 1 birimlik artış, çalışan performansı puanında 0,304 birimlik bir artışa sebep olmaktadır. Söz konusu ilişki istatistiksel olarak anlamlı düzeydedir $(\mathrm{p}=0,001)$. Yöneticilerin otantik liderlik özellikleri ile çalışanların performansı arasında anlamlı bir ilişki vardır.

Otantik liderlik ile pozitif psikolojik sermaye arasında pozitif yönlü 0,232 katsayılı bir ilişki gözlenmiştir. Otantik liderlik puanındaki 1 birimlik artı̧, 
pozitif psikolojik sermaye puanında 0,232 birimlik bir artışa sebep olmaktadır. Otantik liderlik ve pozitif psikolojik sermaye puanları arasında belirlenen bu ilişki istatistiksel olarak da anlamlı düzeydedir $(\mathrm{p}=0,012)$. Yöneticilerin otantik liderlik özellikleri ile çalışanların pozitif psikolojik sermaye düzeyleri arasında anlamlı bir ilişki vardır. Çalışan performansı ile pozitif psikolojik sermaye arasında pozitif yönlü 0,704 katsayılı bir ilişki söz konusudur. Pozitif psikolojik sermaye arsındaki 1 birimlik artış, çalışan performansında 0,704 birimlik bir artışa sebep olmaktadır. Açıklanan ölçekler arasındaki ilişki istatistiksel olarak anlamlı düzeydedir ( $\mathrm{p}=0,0001)$. Ölçekler arasında en güçlü ilişki pozitif psikolojik sermaye ve çalışan performansı arasında belirlenmiştir. Çalışanların pozitif psikolojik sermaye düzeyleri ile performansları arasında anlamlı bir ilişki vardır.

Tablo 8. Nedensel (Hiyerarşik) Regresyon Analizi sonuçlarn

\begin{tabular}{llcccccc}
\hline $\begin{array}{l}\text { Bağımsız } \\
\text { Değişken }\end{array}$ & $\begin{array}{l}\text { Bağımlı } \\
\text { Değişken }\end{array}$ & B & SH & $\beta$ & $R^{2}$ & $t$ & $\mathrm{p}$ \\
\hline $\begin{array}{l}\text { Adım } \mathbf{1} \\
\text { Otantik }\end{array}$ & Performans & 0,079 & 0,023 & $\mathbf{0 , 3 0 4}$ & 0,093 & 3,440 & 0,001 \\
\hline $\begin{array}{l}\text { Adım } \mathbf{2} \\
\text { Otantik }\end{array}$ & PPS & 0,213 & 0,083 & 0,232 & 0,054 & 2,561 & 0,012 \\
\hline $\begin{array}{l}\text { Adım } \mathbf{3} \\
\text { PPS }\end{array}$ & Performans & 0,207 & 0,019 & 0,704 & 0,495 & 10,671 & 0,000 \\
\hline Adım $\mathbf{4}$ & & & & & & & \\
PPS & Performans & 0,198 & 0,020 & 0,667 & 0,512 & 9,923 & 0,000 \\
Otantik & Performans & 0,040 & 0,018 & $\mathbf{0 , 1 4 6}$ & 0,512 & 2,169 & 0,032 \\
\hline
\end{tabular}

Ana hipotezdeki aracı değişken (mediator) rolünü ve diğer hipotezleri test etmek için nedensel (hiyerarşik) regresyon analizleri yapılmıştır. Bunun için Baron ve Kenny yöntemi de denilen nedensel adım yaklaşımı uygulanmıştır (Gürbüz ve Şahin, 2018:285). Bu regresyon analizi için dört adımlı bir model oluşturulmuştur (Baron ve Kenny, 1986:1176). Baron ve Kenny yöntemi yukarıdaki 1 ve 3'ncü adımlar birleştirilerek 3'lü bir model olarak ta uygulanabilmektedir.

Tablo 8'de adım 1'e bakıldığında otantik liderlik ve çalışan performansı arasında pozitif ve anlamlı bir etkileşim vardır $(\mathrm{p}=0,001<0,05)$. Beta sayısı 0,304 olup etkileşim orta seviyededir. Bu durumda H1 hipotezimiz kabul edilmiştir. Yöneticilerin otantik liderlik özellikleri çalışanlarn performansinı anlamlı ve olumlu yönde etkilemektedir. Adım 2'de yer alan regresyon 
analizine göre otantik liderlik özellikleri ve psikolojik sermaye arasında pozitif ve anlamlı bir etkileşim vardır $(\mathrm{p}=0,012<0,05)$. Ancak bu etkileşim zayıf düzeydedir ( $\beta=232)$. Buna göre $\mathrm{H} 2$ hipotezimiz kabul edilmiştir. Yöneticilerin otantik liderlik özellikleri çalışanlarn pozitif psikolojik sermaye dïzeylerini anlamlı ve olumlu yönde zayıf olsa da etkilemektedir. Pozitif psikolojik sermaye ve çalışan performansı arasındaki regresyon analizine göre ise (adım 3) aralarında güçlü ve anlamlı bir etkileşim vardır $(\beta=704, p=0,000<0,05)$. H3 hipotezimiz kabul edilmiştir. Yöneticilerin pozitif psikolojik sermaye düzeyleri çalışanlarm performanslarmı anlamlı ve olumlu yönde etkilemektedir.

Bağımsız değişken (otantik liderlik), aracı değişken (pozitif psikolojik sermaye) ile bağımlı değişken (çalışan performansı) 4'ncü adımda birlikte regresyon analizine tabi tutulmuştur. Buradaki sonuçta eğer bağımsız değişkenin bağımlı değişken üzerindeki etkisi tamamen ortadan kalkıyor ise "tam aracılık", bağımsız değişkenin bağımlı değişken üzerindeki etkisi azalıyor ise "kısmi aracillk" rolünden bahsedebiliriz.

Adım 4'de otantik liderliğin etkileşimi azalmaktadır (0,304'ten 0,146'ya düşmektedir). Bağımlı değişkenin etkisi azaldığından pozitif psikolojik sermayenin kısmi aracılık rolü bulunmaktadır. Bulunan sonuç ise anlamlıdır $(p=0,032<0,05)$. Aracilık rolünün etkisi Sobel testi ile sınanmıştır. Test sonuçları anlamlıdır ve ulaşılan sonucu desteklemektedir $(\mathrm{z}=2,50, \mathrm{p}=0,012<0,05)$. Ayrıca bağımsız değişkenler bağımlı değişkenin \%51,2'sini açılamaktadırlar ( $\mathrm{R} 2=0,512)$. Bu sonuçlara göre $\mathbf{H} 4$ hipotezimiz kabul edilmiştir. Buna göre psikolojik sermaye, otantik liderlik tarzı ile çalışanlarn performansı arasındaki ilişkide kısmi olarak aracılık etkisine sahiptir.

\section{Tartışma ve Sonuç}

Otantik liderlik ve psikolojik sermaye, modern çağın şartlarının ortaya çıkardığı, psikolojik örgütsel davranış alanına yeni bakış açıları getiren yaklaşımlardır. Çalışmada işgörenlerin liderlerine ilişkin otantiklik algısı ile çalışan performansı arasındaki ilişki ve bu ilişkiye çalışanların pozitif psikolojik sermayenin aracılık edip etmediği belirlenmeye çalışılmıştır. Sosyal psikoloji alanında iki önemli kuram olan Lider-Üye Etkileşim Kuramı (LMX Theory) ve Sosyal Değişim Kuramı (Social Exchange Theory) çerçevesinde bir model oluşturulmuştur. Elde edilen bulgular, otantik liderliğin çalışan performansı 
üzerindeki etkisini ve bu etkide pozitif psikolojik sermayenin aracı rolü olduğu yönündeki modelimizi ve hipotezimizi doğrulamıştır.

Daha önce yapılan çalışmalarda Tercan (2017) ve Buldu (2016:87) otantik liderlik ile karizmatik liderliğin çalışan motivasyonunu ve iş performansını etkilediğini, Çiftçi (2018), Taşan (2015), Hırlak (2015) ve Şengüllendi ve Şehitoğlu (2017) otantik liderliğin pozitif psikolojik sermayeyi etkilediğini, Ateş ve Turgut (2018) ve Özkan (2018) ise psikolojik sermayenin çalışan performansını olumlu yönde etkilediğini ve yükselttiğini tespit etmişlerdi. Yapılan çalışmada benzer sonuçlara ulaşılmıştır. Topaloğlu ve Özer (2014) bir holdingin tüm çalışanları arasında yaptığı çalışmada, psikolojik sermaye ile iş performansı arasındaki ilişkide ve otantik liderliğin düzenleyici etkisi incelemişler ve kısmi biçimde düzenlediğini bulmuşlardı. Çalışmada elde edilen sonuç benzer şekildedir.

Otantik liderler takipçilerinin pozitif psikolojik sermayeleri üzerinde davranışları yolu ile etkili olurlar. Böylece örgütlerin performansına ve etkinliğine katkıda bulunurlar. Araştırmada da ortaya çıktı̆̆ gibi otantik liderlik ve pozitif psikolojik sermaye bir bütünün parçaları gibidir. Otantiklik çalışanı olumlu yönde etkiler, bu da çalışanın performansını artırır. Şeffaflık, ahlaki davranış, tarafsızlık ve öz farkındalık gibi otantik özellikler çalışanlar tarafından olumlu algilanmakta ve pozitif psikolojik sermayeyi şekillendirmektedir.

İşgörenin psikolojik sermaye düzeyinin artırabileceğini göz önünde tutarsak, örgütlerin ve işgörenlerin bu hususu geliştirmek için gayret içerisinde olmaları önem arz etmektedir. Bunun için kişi önce kendini tanımalı ve doğrularının peşinden giderek bunu artırma çabasında olmalıdır. Zayıf taraflarını igeliştirmek için gerek kendisi, gerekse örgüt birlikte çabalamalıdır. Yöneticilerin otantik yaklaşımları ise muhakkak ki burada geliştirici bir faktör olacaktır. Performansı tetikleyen, verimlilik artışı ve rekabet avantajı sağlayan örgütsel psikolojik sermaye ve otantik liderlik; kamu, özel sektör veya sivil toplum kuruluşları gibi her türlü örgütsel yapı açısından sahip olunması gereken unsurlar olarak değerlendirilmektedir. 
EXTENDED ABSTRACT

\title{
The Role of Positive Psychological Capital in The Effect of Authentic Leadership on The Performance of Municipal Employees
}

\author{
Rifat İraz - Namik Ata \\ Selçuk University
}

The concepts of authentic leadership and positive psychological capital are increasingly taken place in organizations today, and employers prefer authentic leaders because of their positive contribution to employee performance. Positive psychological capital and authentic leadership can be two elements that complement each other and affect employee performance. This study examines authentic leadership, positive psychological capital, and employee performance.

Leadership is the art and capacity to lead people to a common goal, and it can be described that it is the power to make something embrace and make it happen. The person who has this power is called as leader. If we consider leadership as a function; the leader himself, his followers, goals, environment and conditions are sub-parts of this function (Şimşek ve Çelik, 2017, p.69). Manager and Leader are different concepts, although there are similarities between them. Leader; while motivating and directing people in certain directions for specific purposes, the manager; someone who carries out and manages the existing works, follows the tasks to be done with the given power, and evaluates the results obtained at the end of the planning. The leader uses his own skills rather than his power (Taşan, 2015, p.11,12).

Authentic leadership is one of the most researched leadership styles in recent years, which has positive elements within contemporary leadership approaches (Avolio vd., 2004, p.801) , contributes to organizational outcomes because of its good working environment and moderate organizational climate (Gardner vd., 2005, p.343). The authentic leadership style for the positive feelings of the employees is based on the concept of authenticity. Although it is a concept that has been discussed in the literature since the 1990s, its historical 
history is quite old (Karatürk, 2015, p.11). The word "authentique", which comes into our language from French, means "has the characteristics that have existed since the past" according to TDK (TDK.com, 2019). In other words, it means truth, fidelity, correct, proper and original.

Authentic leadership develops with its followers, it can have a value with them. Followers can shape the leader's behavior (Eagly, 2005, p.459). The followers can decide the authenticity of the leader, authenticity control is how the behaviors of the leader are seen by other people (Goffee ve Jones, 2005, p.1). The authentic leadership structure can be explained in four ways. First, the leadership of authentic leaders is not an imitation. They behaive as they are, they are original. The latter they lead for not promotion or dignity, but for their beliefs and their true selves. Third, they act in line with their values and beliefs, there is a consistency between what they say and what they do. The last feature is that authentic leaders pioneer in maintaining a value-based mission depended on their own beliefs (Shamir ve Eilam, 2005, p.396,397).

The notion of performance; is a concept used to indicate what groups or employees working in the organization are doing, their efforts and what they have achieved in the end (Buldu, 2016, p.59). According to the dictionary, performance means to overcome a job and to complete its task effectively (Akyol, 2015, p.59). The success of the organizations depends on the performance of the staff. Factors such as in-service training, promotion, wage increase, premium, bonuses, holidays are effective strategies to increase the performance of the personnel. High employee performance is also an important issue for organizations, managers and employees. It is an important factor that staff who has a high salary, a good career and good reputation, get pride and statisfaction while achieving success (Tayfun ve Çatır, 2013, p.120). Elements of performance; productivity, efficiency and quality. In addition, it has three different dimensions: individual, team and organizational.

According to Seligman (2002, p.4), who first mentioned this concept, psychology science has three main missions; to heal mental illnesses, to make life more meaningful and productive for individuals, and to make them aware of their abilities, strengths and potentials. However, according to Seligman, psychology science does not fulfill these last two missions (Akçay, 2011, p.77). After making this determination, Seligman suggested the concept of "positive psychology" by emphasizing that psychological findings should be used 
to teach people how to be more normal, happier, more successful and better (Keleş, 2011, p.346).

Our assessment of a business only by looking at its written balance sheet, material capital and profitability may mislead us. The psychological capital of the employees, including optimism, self-efficacy, hope and resilience; human capital, which is formed by his talents, patience, creativity, farsightedness, knowledge and educational level; social capital, which defines its relations with, networks, norms and values, is the intangible capital that does not appear on the balance sheet of the organization, which makes it successful (Özkan, 2018, p.16).

Contemporary competitive conditions, being able to compete with other organizations and gain superiority is not only due to material capital, but also to having intangible human and social capital, namely, educated, experienced and knowledgeable employees. With the increasing importance of the human element in organizations, the meaning of capital has expanded and "psychological capital" has been added to this concept. Psychological capital is one of the most important factors that ensure the survival and resilience of institutions both in the difficult competition conditions of the market and in the crises experienced in the market (Özkan, 2018, p.16).

Authentic leadership and psychological capital are approaches that are brought about by the conditions of the modern age and bring new perspectives to the field of psychological organizational behavior. In the study, it has been tried to determine the relationship between the perception of the employees' authenticity and employee performance and whether or not the positive psychological capital of the employees mediated this relationship. A model has been created within the framework of the Leader-Member Exchange Theory (LMX Theory) and Social Exchange Theory, which are two important theories in the field of social psychology. The findings has confirmed the effect of authentic leadership on employee performance and positive psychological capital plays a mediating role in this effect.

Considering that the psychological capital level of the employee can be increased, it is important for organizations and employees to strive to improve this issue. Therefore, the person must first recognize himself and try to increase it by going after their truth. Both employee and the organization must work together to develop his/her weakness. Hence authentic approac- 
hes of managers will surely be a developing factor in this regard. Organizational psychological capital and authentic leadership are concepts that trigger performance, increase productivity and gain competitive advantage. Therefore, it is considered that these are the terms which all kinds of organizational structures such as public, private sector or non-governmental organizations must have.

\section{Kaynakça / References}

Akçay, V. H. (2011). Pozitif psikolojik sermaye kavramı ve işletmelerde sürdürülebilir rekabet üstünlüğünü sağlamadaki rolü. Gazi Üniversitesi İktisadi ve İdari Bilimler Fakültesi Dergisi, 13(1), 73-98.

Akgündüz, Y. (2012). Konaklama işletmelerinde otantik liderlik ve öz yeterlilik arasındaki ilişkinin analizi. Doktora Tezi, DEÜ Sosyal Bilimleri Enstitüsü,

Akyol, S. (2015). Strateji, liderlik ve çalışan performansı. Yüksek Lisans, Beykent Üniversitesi, İstanbul.

Ateş, M. F. ve Turgut, H. (2018). Psikolojik sermayenin iş performansına etksisnde örgütsel özdeşleşmenin aracılık rolü. Uluslararası İktisadi ve İdari Incelemeler Dergisi, 781-798.

Avey, J. B., Luthans, F. ve Jensen, S. M. (2009). Psychological capital: A positive resource for combating employee stress and turnover. Human resource management, 48(5), 677-693.

Avolio, B. J. ve Gardner, W. L. (2005). Authentic leadership development: Getting to the root of positive forms of leadership. The leadership quarterly, 16(3), 315-338.

Avolio, B. J., Gardner, W. L., Walumbwa, F. O., Luthans, F. ve May, D. R. (2004). Unlocking the mask: A look at the process by which authentic leaders impact follower attitudes and behaviors. The leadership quarterly, 15(6), 801-823.

Blau, P. (1964). Exchange and power in social life: Routledge.

Buldu, T. (2016). Karizmatik liderllik ve çalı̧an performansı ilişkisi: Bir örnek olay araştrrması. Yüksek Lisans Tezi, Okan Üniversitesi Sosyal Bilimler Enstitüsü, İstanbul.

Burns, J. Z. ve Otte, F. L. (1999). Implications of leader-member exchange theory and research for human resource development research. Human Resource Development Quarterly, 10(3), 225-248.

Çetin, F. ve Basım, H. N. (2012). Örgütsel psikolojik sermaye: Bir ölçek uyarlama çalışması. Amme İdaresi Dergisi, 45(1), 121-137. 
Çiftçi, D. Ö. (2018). Otantik liderlik tarzı ve çalışanların işe adanmışlıkları arasındaki ilişkide pozitifpsikolojik sermayenin aracı değişken rolü. Bolu Abant İzzet Baysal Üniversitesi Sosyal Bilimler Enstitüsü, Bolu.

E. P. Seligman, M. ve Csikszentmihalyi, M. (2000). Positive psychology: An introduction (Vol. 55).

Eagly, A. H. (2005). Achieving relational authenticity in leadership: Does gender matter? The leadership quarterly, 16(3), 459-474.

Gardner, W. L., Avolio, B. J., Luthans, F., May, D. R. ve Walumbwa, F. (2005). "Can you see the real me?" A self-based model of authentic leader and follower development. The leadership quarterly, 16(3), 343-372.

Goffee, R. ve Jones, G. (2005). Managing authenticity: The paradox of great leadership. harvard business review, 83(12), 85-94.

Graen, G. B. ve Uhl-Bien, M. (1995). Relationship-based approach to leadership: Development of leader-member exchange (LMX) theory of leadership over 25 years: Applying a multi-level multi-domain perspective. The leadership quarterly, 6(2), 219-247.

Gürbüz, S. ve Şahin, F. (2018). Sosyal bilimlerde araştırma yöntemleri.

Heather M, S. W. (2012). Authentic leadership, leader-member exchange, and organizational citizenship behavior: A multilevel analysis. (Doctorate), The Graduate College at the University of Nebraska.

Hirlak, B. (2015). Otantik liderlik, insan kaynaklar yönetimi uygulamalar ve psikoljik sermaye arasındaki ilişki: Sağlık sektöründe bir araştrıma. Kahramanmaraş Sütçü İmam Üniversitesi Ssosyal bilimler Enstitüsü,

Hirschman, A. O. (1970). Exit, voice, and loyalty: Responses to decline in firms, organizations, and states (Vol. 25): Harvard university press.

Jogulu, U. D. ve Wood, G. J. (2006). The role of leadership theory in raising the profile of women in management. Equal opportunities international, 25(4), 236-250.

Karatürk, H. E. (2015). Otantik ve psikolojik sermaye arasındaki ilişkiye yönelik bir alan araştırması. Yüksek Lisans, Adnan Menderes Üniversitesi, Aydın.

Keleş, H. N. (2011). Pozitif psikolojik sermaye: Tanımı, bileşenleri ve örgüt yönetimine etkileri. Organizasyon ve Yönetim Bilimleri Dergisi, 3(2), 343-350.

Kernis, M. H. (2003). Toward a conceptualization of optimal self-esteem. Psychological inquiry, 14(1), 1-26.

Kernis, M. H. ve Goldman, B. M. (2006). A multicomponent conceptualization of authenticity: Theory and research. Advances in experimental social psycho$\log y, 38,283-357$. 
Kılınç, S. ve Yener, S. (2019). İşkolikliğin örgütsel bağlllık ve performans arasındaki ilişkide aracı rolü. Adıyaman Üniversitesi Sosyal Bilimler Enstitüsü Dergisi, 33, 678-713.

Koçel, T. (2018). İşletme yöneticiliği (17nci Baskı ed.). İstanbul: Beta Basım Yayım Dağıtım A.Ş.

Luthans, F., Avolio, B. J., Avey, J. B. ve Norman, S. M. (2007). Positive psychological capital: Measurement and relationship with performance and satisfaction. Personnel Psychology, 60(3), 541-572.

Luthans, F., Avolio, B. J., Walumbwa, F. O. ve Li, W. (2005). The psychological capital of Chinese workers: Exploring the relationship with performance. Management and Organization Review, 1(2), 249-271.

Luthans, F., Luthans, K. W. ve Luthans, B. C. (2004). Positive psychological capital: Beyond human and social capital. Bussiness Horizons, 47(1), 45-50.

Luthans, F. ve Youssef, C. M. (2004). Human, social, and now positive psychological capital management: Investing in people for competitive advantage. Organizational Dynamics, 33(2), 143-160.

Özkan, O. S. (2018). Psikolojik sermayenin bireysel performans üzerindeki etkisinde birey-örgüt uyumunun aracılık rolü. Doktora Tezi, Türk Hava Kurumu Üniversitesi, Ankara.

Seligman, M. E. (2002). Positive psychology, positive prevention, and positive therapy. Handbook of positive psychology, 2(1), 3-12.

Shamir, B. ve Eilam, G. (2005). "What's your story?" A life-stories approach to authentic leadership development. The leadership quarterly, 16(3), 395-417.

Sparrowe, R. T. (2005). Authentic leadership and the narrative self. The leadership quarterly, 16(3), 419-439.

Survey.com. (2019). Survey Size Calculator. https://www.surveysystem.com/sscalc.htm. www.survey.com adresinden erişilmiştir.

Şengüllendi, M. F. ve Şehitoğlu, Y. (2017). Dönüşümcü liderlik ve pozitif psikolojik sermaye ilişkisinde eğitim düzeyinin moderatör rolü. Yıldız Sosyal Bilimler Enstitüsü Dergisi, 1(2), 112-126.

Şimşek, M. Ş. ve Çelik, A. (2017). Yönetim ve organizasyon: Eğitim Kitabevi.

Tabak, A., Polat, M., Coşar, S. ve Türköz, T. (2012). Otantik liderlik ölçeği: Güvenirlik ve geçerlik çalışması. ISGUC The Journal of Industrial Relations and Human Resources, 14(4), 89-106.

Taşan, H. (2015). Ilköğretim kurumlarında görev yapan yöneticilerin otantik liderlik ve psikolojik sermaye düzeylerinin karşılaştırlması. Zirve Üniversitesi Sosyal Bilimler Enstitüsü, 
Tayfun, A. ve Çatır, O. (2013). Örgütsel sessizlik ve çalışanların performansları arasındaki ilişki üzerine bir araştırma. İşletme Araştırmaları Dergisi, 5(3), 114-134.

TDK.com. (2019). Güncel Türkçe sözlük.

Teke, A. (2017). Dönüşümcü liderliğin örgütsel bağhllğa etkisinde çalışan performanstnın rolü: Havacılık sektöründe bir uygulama. (Yüksek Lisans Tezi), Gediz Üniversitesi Sosyal Bilimler Enstitüsü,

Tercan, S. (2017). Otantik liderliğin çalşan performansina ve iş performansina etkisi. (Yüksek Lisans Tezi), İstanbul Arel Üniversitesi,

Topaloğlu, T. ve Özer, P. S. (2014). Psikolojik sermaye ile iş performansı arasındaki ilşikiye otantik liderliğin düzenleyici etkisi. Organizasyon ve Yönetim Bilimleri Dergisi, 6(1), 156-171.

Walumbwa, F. O., Avolio, B. J., Gardner, W. L., Wernsing, T. S. ve Peterson, S. J. (2008). Authentic leadership: Development and validation of a theorybased measure. Journal of management, 34(1), 89-126.

Yener, S. (2018a). Psikolojik rahatlık algısının otantik liderliğin sinizmin üzerindeki etkisinde aracı rolü. Eskişehir Osmangazi Üniversitesi İktisadi ve İdari Bilimler Dergisi, 13(1), 1-14.

Yener, S. (2018b). Sosyal bilimlerde kuramın rolü. Sosyal Bilimler Araştırma Dergisi, $7(3), 102-113$.

Yılmaz, A. ve Yılmaz, H. U. (2016). Pozitif psikolojik sermayenin algılanan performans düzeyine etkisinde örgütsel adanmışlığın aracılık rolü: bir hizmet işletmesinde araştırma. Anadolu Üniversitesi Sosyal Bilimler Dergisi, 18(3), 129-144.

\section{Kaynakça Bilgisi / Citation Information}

İraz, R. ve Ata, N. (2020). Otantik liderliğin belediye çalışanlarının performansina etkisinde pozitif psikolojik sermayenin rolü. OPUS-Uluslararası Toplum Araştırmaları Dergisi, 16(27), 288-318. DOI: 10.26466/opus.643236 